\title{
Effects of portal infusions of methionine on plasma concentrations and estimated hepatic balances of metabolites in underfed preruminant calves
}

\author{
Y Chilliard ', C Audigier ' 1, D Durand 2, S Auboiron 2, D Bauchart ${ }^{2}$ \\ 1 INRA, Laboratoire Sous-Nutrition des Ruminants, \\ 2 INRA, Laboratoire Croissance et Métabolismes des Herbivores, \\ Theix, 63122 Saint-Genès-Champanelle, France
}

The effects of portal infusions of methionine (Met) were studied in 6 preruminant male calves fed a conventional milk replacer in order to allow a daily body gain of $650 \mathrm{~g}$ (days 8-15 after birth) except during the experimental period (days 18-25 after birth) when the growth rate was lowered to about $200 \mathrm{~g} / \mathrm{d}$ (instead of $1000 \mathrm{~g} / \mathrm{d}$ at this age) by a $45 \%$ restriction in feed allowance. Animals were fitted with catheters in the mesenteric artery (MA), the portal vein and one of the hepatic veins at 8 days of age.

After $5 \mathrm{~d}$ of feed restriction, metabolite concentrations were determined in the 3 blood vessels $7 \mathrm{~h}$ after the morning feeding with a view to calculating the estimated hepatic balances (EHB) using estimates of blood flows, according to body weight and previous equations (Durand et al, 1988). After a control measurement on day 23 , Met was infused in the portal vein for $7 \mathrm{~h}$ after the morning feeding at dose 1 (day 24) and dose
2 (day 25). Met allowances were 2.4, 3.0 and 3.6 $\mathrm{g} / 100 \mathrm{~g}$ of protein in the milk replacer (control, dose 1 and dose 2, respectively).

Met infusion at dose 2 decreased triglyceride, non-esterified fatty acid and 3-hydroxybutyrate plasma concentrations in the mesenteric artery. The EHB of glucose was significantly increased by this infusion. There was a trend to decrease the apparent captation of triglycerides and to decrease the apparent productions of non-esterified fatty acids and 3-hydroxybutyrate. These results suggest that an increase in Met availability in the energy- and protein-underfed calf can increase hepatic gluconeogenesis, without increasing ketogenesis, perhaps because of a stimulation of triglyceride secretion (thus decreasing the apparent triglyceride capture).

Durand D, Bauchart D, Lefaivre J, Donnat JP (1988) J Dairy Sci 71, 1632-1637

Table I. Effects of methionine (Met) infusions on hepatic metabolism of plasma metabolites.

\begin{tabular}{|c|c|c|c|c|c|c|}
\hline \multirow[t]{2}{*}{ Metabolite } & \multicolumn{2}{|c|}{ Control } & \multicolumn{2}{|c|}{ Met-dose 1} & \multicolumn{2}{|c|}{ Met-dose 2} \\
\hline & $M A^{1}$ & $E H B^{2}$ & $M A$ & $E H B$ & MA & $E H B$ \\
\hline Glucose $^{3}$ & 0.90 & 1.5 & 0.92 & 1.5 & $0.87^{\mathrm{b}}$ & $1.9^{*}$ \\
\hline Triglycerides $^{3}$ & 0.31 & -3.7 & 0.29 & 0.8 & $0.21^{\star \star a}$ & -0.5 \\
\hline Non-esterified fatty acids 4 & 1.40 & 29.2 & $1.05+$ & 0.6 & $0.55^{+}$ & 3.2 \\
\hline 3-Hydroxybutyrate 4 & 0.07 & 1.0 & $0.05+$ & 0.4 & 0.04 ** & 0.5 \\
\hline Urea $^{3}$ & 0.15 & 0.3 & 0.15 & 0.1 & 0.15 & 0.4 \\
\hline
\end{tabular}

\footnotetext{
1 Concentration in the mesenteric artery $(n=6) ;{ }^{2}$ estimated hepatic balance: apparent production, or $(-)$ capture. Due to failure in the hepatic vein catheter, EHB balances were only available on 5 (control) and 4 (Met-dose 1 and Met-dose 2) calves; ${ }^{3} \mathrm{mg} / \mathrm{ml}$ (MA) or $\mathrm{mg} / \mathrm{min} / \mathrm{kg}$ body weight (EHB); ${ }^{4} \mathrm{mM}$ (MA) or $\mu \mathrm{mol} / \mathrm{min} / \mathrm{kg}$ body weight (EHB);,$+ *$ " significantly different from control-value, $P<0.11,0.06,0.03$, respectively; ${ }^{a, b}=$ significantly different from dose $1-$ value $(P<0.11,0.03$, respectively).
} 